\title{
Intracardiac Scanning of the Heart with the Aid of Ultrasonic Intravenous Probe
}

\author{
Ryozo Омото, M.D.
}

W

ITHIN the recent decade, distinguished advancement has been made in application of ultrasound in various medical fields. ${ }^{1 \prime}$ Ultrasonic technique can realize images of the soft tissues by both absorption and reflection, which structure is more clearly identified with this technique than with $\mathrm{X}$-ray in a fine contrast due to different propagation constants of ultrasound between tissues. A number of investigators have focused their efforts on visualization of the soft tissue structure and its movement by various pulse-reflection methods. These methods have been proved of a great diagnostic value and have appeared to be promising to the future.

One of the advantages of ultrasonic diagnosis is absence of pain and diagnostic surgery. However, if a little surgery is added, application of this diagnostic method is extended. As for application to the heart, conventional ultrasonic echography through the chest wall $^{2,3)}$ is limited in indication and in result, being disturbed by precardiac tissues as well as air in the lung.

In 1960 , Cieszynski ${ }^{4}$ reported the intracardiac method with a miniature ultrasonic probe inserted into the heart lumen through the jugular vein of an anesthetized $\operatorname{dog}$ and he obtained reflections of ultrasound from the surface of the right and left heart lumen as well as from the great vessels without any harm.

Since 1962, the author ${ }^{5)-7)}$ devised and applied the ultrasonic intravenous probe to animals and patients with heart diseases, which is called the " cardiac sonde" while another probe for detecting liver lesions is called the "liver sonde" which was introduced in our previous papers. ${ }^{6,8)}$

In this paper, principle, procedures and results of the intracardiac ultrasonic scanning inside the heart with this probe are described with a focus in detection of atrial septal defect of the heart.

\section{Methods ANd Materials}

The ultrasonic intravenous probe: Since the first ultrasonic intravenous probe was made by the author for clinical examination in 1962, various types of probe

From the Departments of Surgery and Thoracic Surgery, Faculty of Medicine, University of Tokyo, Tokyo.

Received for publication April 11, 1967. 
Table I. Review of Characteristics of the Probes

\begin{tabular}{|c|c|c|c|c|c|c|c|}
\hline No. & $\begin{array}{c}\text { Transducer } \\
\text { diameter } \\
\text { mm. }\end{array}$ & $\begin{array}{l}\text { Frequency } \\
\text { Mc./sec. }\end{array}$ & $\begin{array}{l}\text { Diameter } \\
\mathrm{mm} \text {. }\end{array}$ & $\begin{array}{c}\text { Length } \\
\text { mm. }\end{array}$ & $\begin{array}{l}\text { Material and } \\
\text { outside diameter } \\
\text { of rod }\end{array}$ & $\begin{array}{l}\text { Directivity } \\
\text { deg. of arc }\end{array}$ & Use for \\
\hline 1 & $\begin{array}{l}\text { Quartz } \\
\text { crystal } 5\end{array}$ & 10 & 5.4 & 480 & $\begin{array}{l}\text { Lehman's } \\
\text { catheter No. } 13\end{array}$ & 2 & Heart \\
\hline 2 & $\begin{array}{l}\text { Quartz } \\
\text { crystal } 5\end{array}$ & 5 & 5.4 & 480 & $\begin{array}{l}\text { Lehman's } \\
\text { catheter No. } 13\end{array}$ & 4 & $\begin{array}{l}\text { Heart } \\
\text { and liver }\end{array}$ \\
\hline 3 & $\underset{\text { titanate } 5}{\text { Barium }}$ & 5 & 3.6 & 600 & $\begin{array}{l}\text { Lehman's } \\
\text { catheter No. } 10\end{array}$ & 6 & $\begin{array}{l}\text { Heart } \\
\text { and liver }\end{array}$ \\
\hline 4 & $\begin{array}{l}\text { Barium } \\
\text { titanate } 2\end{array}$ & 5 & 3.4 & 750 & $\begin{array}{l}\text { Pipe of stainless } \\
\text { steel } 1.2 \mathrm{~mm} \text {. }\end{array}$ & 6 & Heart \\
\hline 5 & $\underset{\text { titanate }}{\text { Barium }}$ & 2.25 & 6.0 & 750 & $\begin{array}{l}\text { Pipe of stainless } \\
\text { steel } 2.0 \mathrm{~mm} .\end{array}$ & 5 & Liver \\
\hline 6 & $\begin{array}{l}\text { Barium } \\
\quad \text { titanate } 2\end{array}$ & 5 & 3.4 & 750 & $\begin{array}{l}\text { Pipe of stainless } \\
\text { steel } 1.2 \mathrm{~mm} \text {. }\end{array}$ & 6 & Heart \\
\hline 7 & $\begin{array}{l}\text { Barium } \\
\text { titanate } 2\end{array}$ & 5 & 3.4 & 750 & $\begin{array}{l}\text { Pipe of stainless } \\
\text { steel } 1.2 \mathrm{~mm} \text {. }\end{array}$ & 6 & Heart \\
\hline 8 & $\underset{\text { titanate } 5}{\text { Barium }}$ & 2.25 & 5.6 & 750 & $\begin{array}{l}\text { Pipe of stainless } \\
\text { steel } 1.2 \mathrm{~mm} \text {. }\end{array}$ & 5 & Liver \\
\hline 9 & $\underset{\text { titanate } 2}{\text { Barium }}$ & 5 & 3.2 & 750 & $\begin{array}{l}\text { Pipe of stainless } \\
\text { steel } 1.2 \mathrm{~mm} .\end{array}$ & 6 & Heart \\
\hline 10 & $\begin{array}{l}\text { Barium } \\
\text { titanate } 2\end{array}$ & 5 & 3.2 & 750 & $\begin{array}{l}\text { Pipe of stainless } \\
\text { steel } 1.2 \mathrm{~mm} .\end{array}$ & 6 & Heart \\
\hline 11 & $\underset{\text { titanate }}{\text { Barium }}$ & 2.25 & 5.0 & 750 & $\begin{array}{l}\text { Pipe of stainless } \\
\text { steel } 1.2 \mathrm{~mm} .\end{array}$ & 6 & Liver \\
\hline 12 & $\underset{\text { titanate }}{\text { Barium }}$ & 2.25 & 5.0 & 750 & $\begin{array}{l}\text { Pipe of stainless } \\
\text { steel } 1.2 \mathrm{~mm} \text {. }\end{array}$ & 6 & Liver \\
\hline 13 & $\begin{array}{l}\text { Barium } \\
\text { titanate } 2\end{array}$ & 5 & 3.2 & 750 & $\begin{array}{l}\text { Pipe of stainless } \\
\text { steel } 1.2 \mathrm{~mm} \text {. }\end{array}$ & 6 & Heart \\
\hline 14 & $\begin{array}{l}\text { Barium } \\
\text { titanate } 2\end{array}$ & 5 & 3.2 & 750 & $\begin{array}{l}\text { Pipe of stainless } \\
\text { steel } 1.2 \mathrm{~mm} .\end{array}$ & 6 & Heart \\
\hline 15 & $\begin{array}{l}\text { Barium } \\
\text { titanate } 2\end{array}$ & 5 & 3.2 & 780 & $\begin{array}{l}\text { Pipe of stainless } \\
\text { steel } 1.2 \mathrm{~mm} \text {. }\end{array}$ & 6 & Heart \\
\hline $16^{*}$ & $\begin{array}{l}\text { Barium } \\
\text { titanate } 2\end{array}$ & 5 & 3.2 & 950 & $\begin{array}{l}\text { Pipe of stainless } \\
\text { steel } 1.2 \mathrm{~mm} \text {. }\end{array}$ & 6 & Heart \\
\hline $17 *$ & $\begin{array}{l}\text { Barium } \\
\text { titanate } 2\end{array}$ & 5 & 3.2 & 950 & $\begin{array}{l}\text { Pipe of stainless } \\
\text { steel } 1.2 \mathrm{~mm} .\end{array}$ & 6 & Heart \\
\hline
\end{tabular}

* The recent model with a special attachment of spring coil.

have been manufactured for trial (Table I). They have different characteristics in materials of electroacoustic transducer and tube, size of probe, attachment device above the transducer and frequency of ultrasound. Early models of probe have a miniature ultrasonic transducer for each at the tip of a tube, from which the ultrasonic 

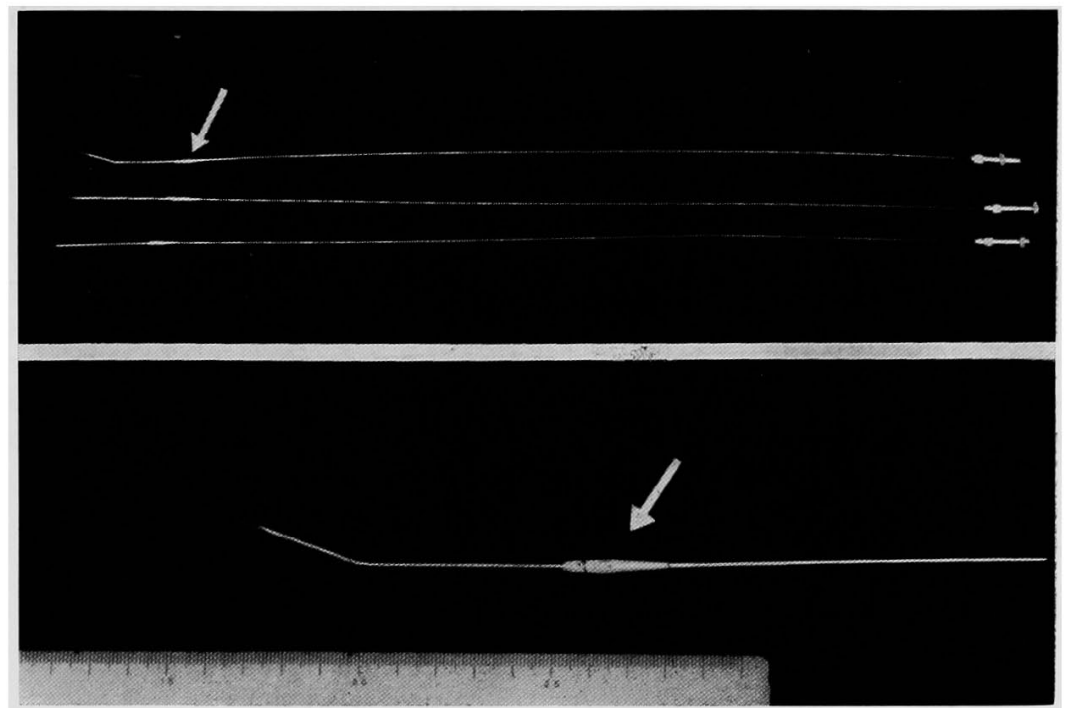

Fig. 1. The ultrasonic intravenous probe of recent model. The arrow points to the transducer.
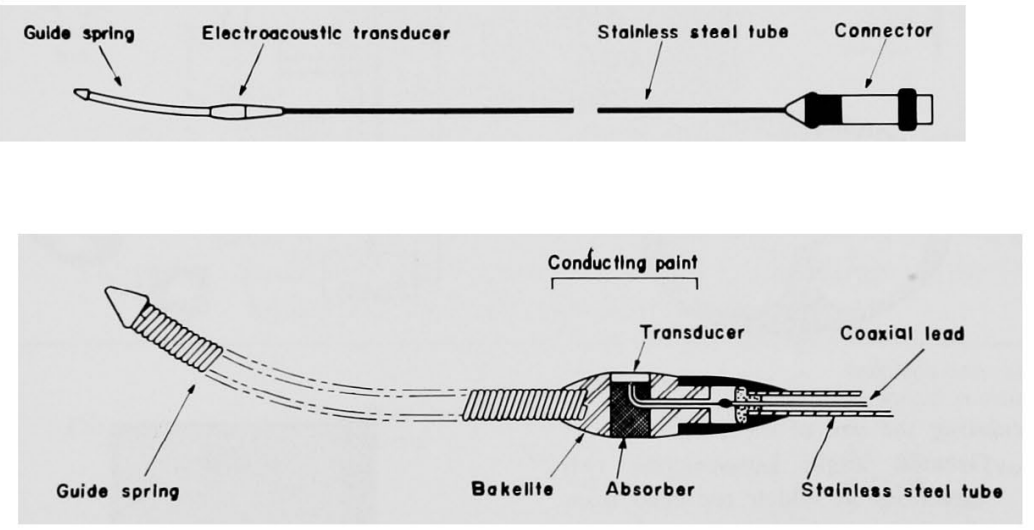

Fig. 2. Cross-sectional view of the probe.

beam comes out perpendicularly to the tube and which receives information by pulse reflection method.

The recent model has a special attachment of about $100 \mathrm{~mm}$. stainless steel coil above the tip of the transducer (Figs. 1 and 2). One of the improved points on employing the probe of this type is that the probe can be inserted more easily and, during the scanning, the transducer can slide almost on the same superior and inferior vena cava line without deviation in the lumen of the right atrium and can be avoided from liability to be placed close to the interatrial septum. A slight bending of the attachment near the top is convenient for easy insertion of the probe into the femoral vein and the superior vena cava through the right atrium.

Most part of the probe is coated with silicone to prevent thrombus formation. 
Probes are sterilized with 1 in 100 solution of benzalkonium chloride or with formalin vapor.

Method of intracardiac scanning ( $C$-scan technique): The procedures of this method are an introduction of the transducer to the right atrium through the femoral vein and a scanning of the inside of the heart covering the area of the interatrial septum by rotating and withdrawing the probe outside the body under X-ray fluoroscopy.

C-scan indication system has been employed with an ECG-synchronized circuit and a variable gate circuit. The former circuit is necessary to nullify the effect of movement of the heart, and the latter circuit is to detect the disappearance of the expected echoes from the interatrial septum, that is, distinguishing the echoes of the septum from those of other origins by an adequate gate distance under a simultaneous A-scope monitoring. As to the ECG-synchronized circuit, transmitting

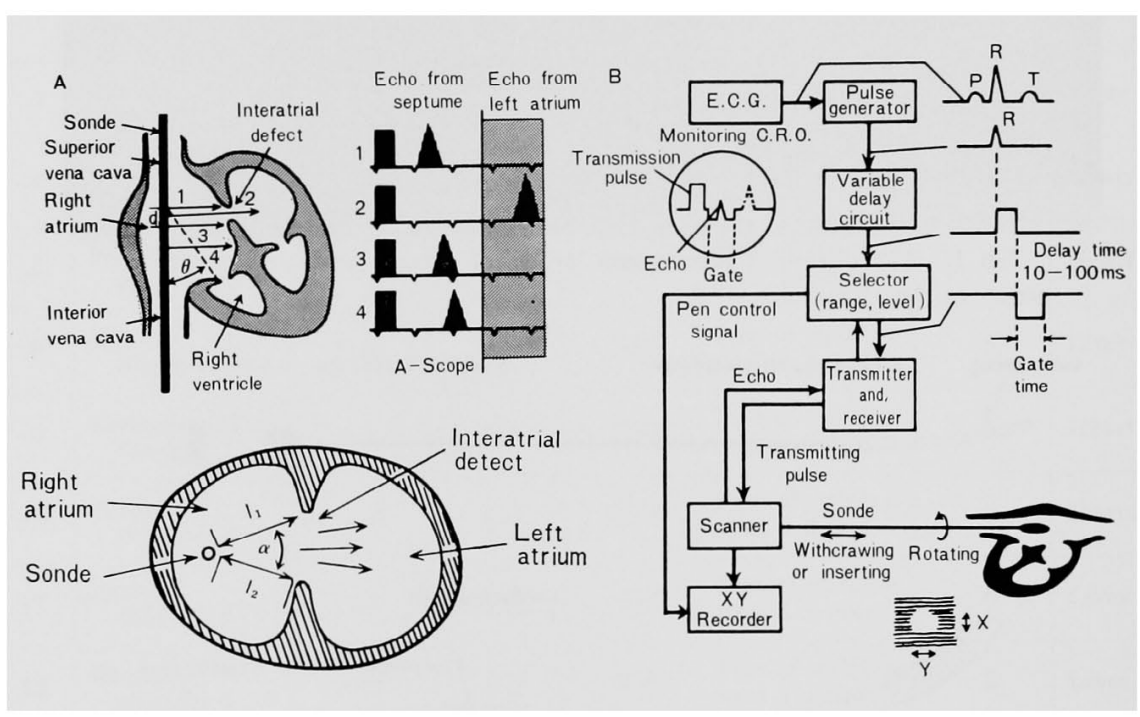

Calculating the size of the a.s.d.

$\alpha$. Greatest angle between the two directions at which the echo from the defect appears

d. Measured height of defect

$\theta$. Angle between sonde and septum

D. True longitudinal length of defect

$D^{\prime}$. True transverse length of defect

$D=d \sec \theta$

$D^{\prime}=\sqrt{l_{1}^{2}+l_{2}^{2}-2 l_{2} l_{2} \cos \alpha}$

and as $l_{1} \simeq l_{2}$

$D \simeq 2 l_{1} \sin \frac{\alpha}{2}$

Fig. 3.

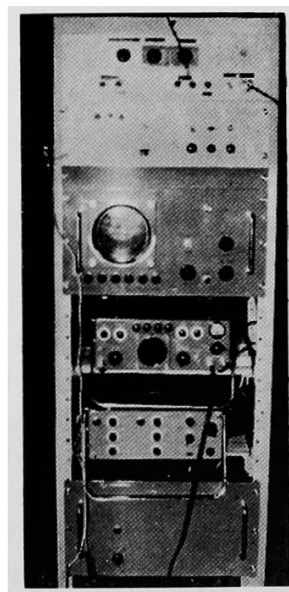

Fig. 4. Whole view of the C-scan apparatus. 
and receiving units are working only for narrow gate time synchronized to ECG. From the experimental results, the gate time of $100 \mathrm{msec}$. is found adequate for neglecting interference accompanied with the heart movement (Figs. 3 and 4).

A X-Y-recorder or a memory tube has been used for recording the image of the defect. The coordinations on X-Y-recorder or memory tube are corresponding to the directions of the transmitting pulse of ultrasound by means of the coupled potentiometers in the scanner. When echoes from the interatrial septum are obtained, the spots of the corresponding coordinations on the recorder are marked

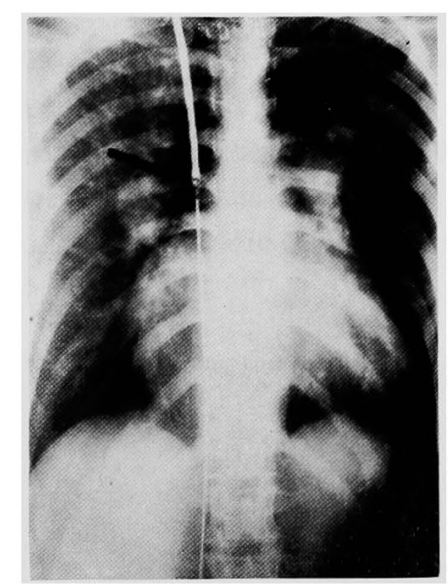

Fig. 5. X-ray of the chest under this examination. The arrow points to the transducer that is located at the end of superior vena cava where scanning is started.

Table II. Summary of Diagnoses and G-Scan Findings of the Examined Patients with Heart Diseases

\begin{tabular}{|c|c|c|c|c|c|}
\hline \multirow{2}{*}{ Diagnosis } & \multirow{2}{*}{$\begin{array}{c}\text { Number of } \\
\text { patient }\end{array}$} & \multicolumn{2}{|c|}{ C-scan image } & \multicolumn{2}{|c|}{$\begin{array}{l}\text { Information by only } \\
\text { A-scope monitoring }\end{array}$} \\
\hline & & $\begin{array}{l}\text { No. of } \\
\text { success }\end{array}$ & No. failed & $\begin{array}{l}\text { No. of } \\
\text { success }\end{array}$ & No. failed \\
\hline ASD & 10 & 5 & & 3 & $2 *$ \\
\hline ASD and (or) VSD & 2 & 1 & $1 *$ & & \\
\hline Normal (preexam. : ASD) & 1 & $1 * *$ & & & \\
\hline ECD & 2 & & 1* & 1 & \\
\hline PS & 3 & 1 & & 1 & $1^{*}$ \\
\hline MS & 1 & & & 1 & \\
\hline Pericarditis & 1 & & & 1 & \\
\hline Total & 20 & 8 & 2 & 7 & 3 \\
\hline
\end{tabular}

* See the text in discussion.

** The case demonstrated in (d) of Fig. 8 
as positive. The location of the defect can be easily measured on the recording by initial location of the transducer at the end of the superior vena cava before scanning the septum (Fig. 5).

Materials of this study: There were three kinds of materials: (1) model slits in various width using pericardium, myocardium, blood vessel and plastic cylinders for in vitro detection, (2) 2 dogs with experimentally produced atrial septal defect and 4 intact dogs and (3) 20 patients with various heart diseases (Table II).

\section{REsults}

In vitro experiment: Theoretical directivity of each transducer shown in Table $I$ is the calculated data. In order to obtain actual data on directivity of the miniature transducer, in vitro examinations to detect the slit of a certain width have been performed using biological and nonbiological models with 1-2 mm. thickness.
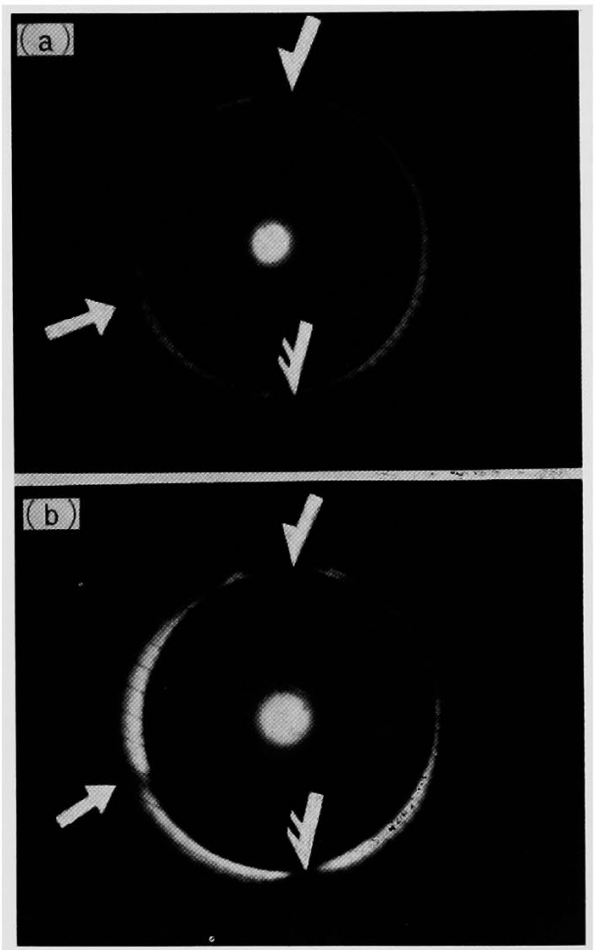

Fig. 6. An example of experiments on directivity of the miniature transducer.

Slits in a plastic model of $77 \mathrm{~mm}$. in diameter are detected.

Transducer: (a); $5 \mathrm{Mc}, 4 \mathrm{~mm} \phi$.

(b); $5 \mathrm{Mc}, 2 \mathrm{~mm} \phi$.

Width of slit: । $20 \mathrm{~mm}$., \& $10 \mathrm{~mm}$., $\searrow 4 \mathrm{~mm}$. 
In each model, the slit of 4 to $7 \mathrm{~mm}$. in width has been easily detected within the area of a quarter circle of $50 \mathrm{~mm}$. in diameter, symmetrical to normal and with the center at the slit.

As a result, it is assured that the slit of over $10 \mathrm{~mm}$. in width can be surely detected with about $20 \%$ measuring error. In Fig. 6, as an example, detection of a $4 \mathrm{~mm}$. slit in a plastic model is demonstrated.

Animal experiment: The C-scan technique has been performed on 2 dogs with experimentally produced atrial septal defect and 4 intact dogs as control. The gate time is varied from 20 to $200 \mathrm{msec}$. with a result of $100 \mathrm{msec}$. as an adequate time for recording and monitoring.

Atrial septal defect of each dog is recorded successfully on X-Y-recorder. The G-scan image of a dog with atrial septal defect is shown in Fig. 7.

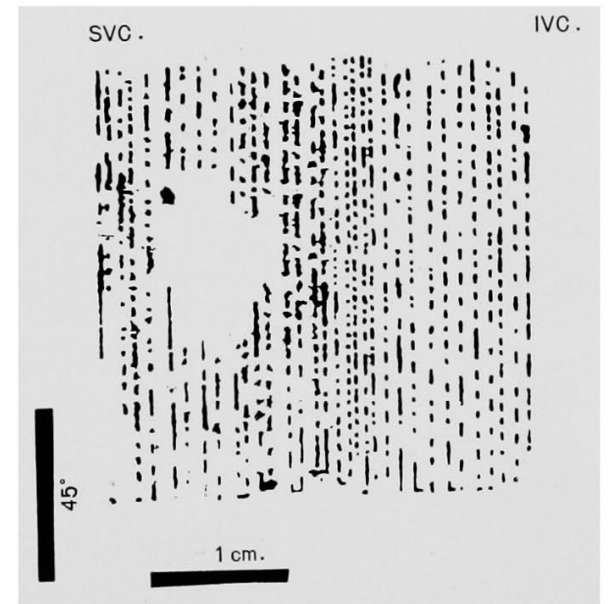

Fig. 7. The C-scan image of a dog with experimentally produced atrial septal defect.

Size of defect (autopsy): $12 \times 10 \mathrm{~mm}$.

Calibrated size of the defect on the recorder is slightly smaller than the actual one measured after sacrifice. Error from the actual size is found about $20 \%$ in over $10 \mathrm{~mm}$. atrial septal defect. This error depends generally on distance between the transducer and the interatrial septum, thickness of the septum, angle of the tube of the probe to the septum, heart rate of the animal, etc.

In the control dogs, disappearance of the expected echoes from the septum is never observed.

Clinical application: For 3 years since the first application in April 1963, the examinations using the ultrasonic intravenous probe have been performed without any complication on 20 patients with various heart diseases at ages 
ranged from 8 to 42 years old. This method is perfectly safe to all patients ; neither fibrillation, flutter of the heart, thrombus formation, infection nor injury to the heart and blood vessels has occurred on ECG or other repeated

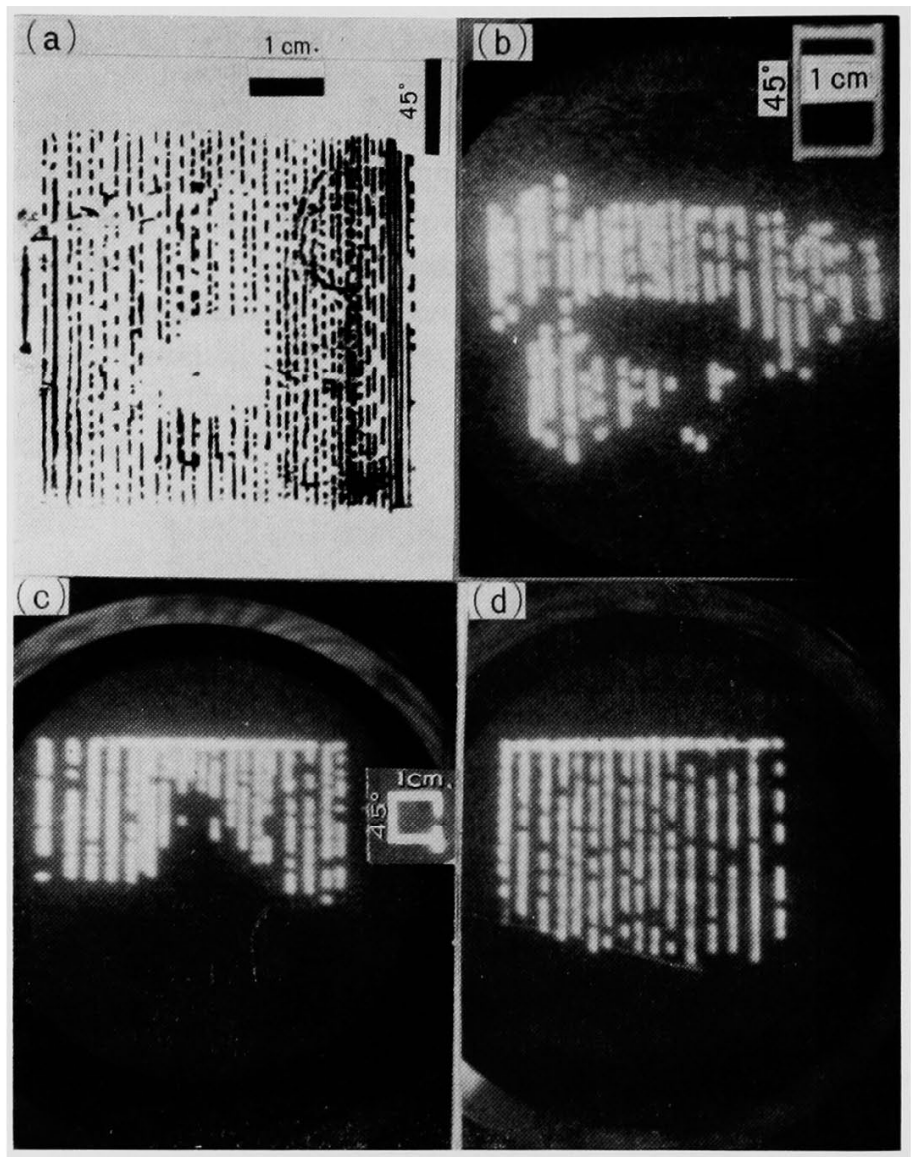

Fig. 8. Records of C-scan image. (In looking at these images the left side is the head side of the septum and the upper side is the right side.)

(a) A 24-year-old male with ASD. Size of defect: $25 \times 15 \mathrm{~mm}$. (calculated), $27 \times 16 \mathrm{~mm}$. (measured under surgery). As a recorder $\mathrm{X}-\mathrm{Y}$-recorder is used.

(b) A 20-year-old female with ASD.

Size of defect: $28 \times 20 \mathrm{~mm}$. (calculated), $35 \times 25 \mathrm{~mm}$. (measured under surgery). As a recorder memory tube is used.

(c) A 14-year-old male with ASD.

Only the right margin of defect is recorded. Size of defect: $28 \mathrm{~mm}$. (calculated, longitudinal length) $33 \times 25 \mathrm{~mm}$. (under surgery).

(d) A 15-year-old male who is suspected of ASD. On the C-scan image no defect is recorded. 
careful examinations during and after procedures. Clinical results of these patients are shown in Table II.

Here, C-scan method does not mean only C-scan image recording but also A-scope monitoring during C-scanning without image recording. From this meaning, only A-scope monitoring has been employed in 10 cases, while G-scan image has been tried to record in 10 cases, in 6 of whom C-scan image of atrial septal defect (ASD) has been recorded successfully.

On 3 cases ( 1 s.o. ASD but normal and 2 pulmonary stenosis) C-scan image of the intact septum without any defect has been clearly recorded. On each case of mitral stenosis and pericarditis, this examination has been performed as control with reasonable results.

Records of C-scan image on 4 cases are demonstrated in Fig. 8 :

(a) in the figures shows C-scan image of the first clinical case of a 24years-old male with ASD. The defect of the interatrial septum is clearly recorded by this method with a relatively small difference between the size calculated on the record and that measured directly during surgery. The former is slightly smaller than the latter.

(b) in Fig. 8 shows another case of a 20-year-old female with ASD. As a recorder a memory tube is used in place of an X-Y-recorder, because it is more convenient to save time for better response to fast scanning.

(c) in Fig. 8 shows another case of a 14-year-old male with ASD which C-scan image of only the right margin of defect has been recorded on the memory tube to save time, which may be satisfactory for clinical diagnosis of the defect and for obtaining the information on location and dimensions of the defect.

(d) in Fig. 8 shows a C-scan image of a 15-year-old male who is suspected of ASD and which data of routine examinations are slightly complicated. On the C-scan image no defect is observed, which means that the atrial septal defect is at least denied.

\section{Discussion}

As to echography of the heart, Wild ${ }^{9 /}$ had reported the experiments with ultrasonotomography of the excised human heart by B-scope without any device to neglect the heart movement.

Any attempt has never been done to apply an intracardiac scan method of ultrasound for detection of heart diseases in human, before and since Cieszyn$\mathbf{s k i}^{4}$ reported his preliminary experiment on the dog of an intracardiac ultrasonic catheter in 1960.

This study has aimed to detect an atrial septal defect with ultrasound in- 
side the heart or to obtain information on the heart structure involving the septum. The image of atrial septal defect was first clearly recorded in our clinical case by G-scan in 1963. As for my original device, probes with the attachment at the tip of transducer may be most convenient to insert, to get orientation and to scan the lumen of the heart.

In comparison with the esophageal approach ${ }^{101,11)}$ or other transthoracic approaches, the intracardiac method seems to be most direct way to reach the heart structure. In other words, when the probe is placed in the right atrium lumen, the first echoes are originated from the heart structure in all directions without complicated echoes from surrounding tissue or organs. This simple fact is very important to interpret the echogram, to measure size and to know location and other structural information of atrial septal defect and others. In spite of a few demerits of this type of miniature probe, which are discussed in the following paragraph, this examination may be of value to be applied for proper indication.

It seems to be not so serious disadvantage that this method needs a little surgery of cut-down of the $v$. saphena magna in the groin, because this examination is usually performed following the routine right heart catheterization through the same venous cut-down without any additional burden to the patient. Although the transducer is placed in the heart lumen and transmits ultrasound towards the heart wall, an average power of ultrasound in pulsed use at the frequency of $5 \mathrm{Mc}$. $/ \mathrm{sec}$. is markedly lower than the minimum injurious limit of the heart structure.

In the ultrasonic pulse-reflection method, the resolving power in the angular direction depends mainly on the frequency of ultrasound and the diameter of the electroacoustic transducer, and that in the distance depends chiefly on the ultrasonic frequency and pulse length which is determined by characteristics of the amplifier and material of the transducer.

One of the demerits of employing this miniature probe is that a relatively poor resolving power is obtained in the angular direction. In order to make up for this demerit, the object must be ranged in shorter distance, so that the resolving power is apparently improved.

The C-scan image is obtained in only a flat one of the defect, though a defect is three-dimensional. It should be emphasized whether or not C-scan image is recorded on X-Y-recorder or memory tube is not essential, because it is only one means to search the defect. Dynamic monitoring by EGG-synchronized A-scope with no disturbance due to the heart movement is rather instructive to get three-dimensional information of the defect.

One of the reasons is that it is not rarely so difficult to set the gate for selecting echoes from the interatrial septum in the C-scan method. The defect 
is rather easily recognized by the A-scope monitoring; that is, the difference between echoes from the right atrial wall including the interatrial septum and those from the left atrial-wall through the atrial septal defect is more detectable by this monitoring. A sharp and sudden change from echo reflection of the septum to that of the left atrial wall at the margin of atrial septal defect gives accurate and dynamic information of size and shape of the defect on the Ascope during scanning.

Measuring error in size of the defect was less than $20 \%$ in the first case which was checked during the open heart operation. In general, the geometric error of this examination may be within about $20 \%$.

Causes of failure in detecting the defect are detailed in the following.

In a case of combination of atrial and ventricular septal defects and another case of pulmonary stenosis, the examination was not completed because of some trouble of the ECG-synchronization. The G-scan image of a case of endocardial cushion defect was not differentiated from that of persistent ostium secundum, because of distorted image of the septum due to an inadequate gate for selecting the echoes.

The fact that adequate determination of the gate was difficult in some cases promoted to advance this study towards further investigation employing automatic or mechanical scanning method instead of manual one, which is the ultrasonic tomography of the heart with intracardiac technique. This will be published in another paper. ${ }^{12}$

Furthermore, in order to create a three-dimensional image, another device is being tried by transforming each gate time into a corresponding color. Its practical usefulness will be discussed in a future article.

Again, the intracardiac scan technique was approved to add more and entirely new value in some aspect to ultrasonic cardiography, which was developed mainly by Edler and $\mathrm{Hertz}^{2,3)}$ aiming to trace movement of the heart and is now standardized as a routine examination for diagnosis of heart diseases in many institutions.

\section{SUMmaRY}

This work has concerned with the experimental and clinical application of an intracardiac scan method with the ultrasonic intravenous probe for diagnosis of heart diseases.

Various types of the ultrasonic intravenous probes have been initially deviced, manufactured and examined by the author with which this work has been able to be performed. The recent model has an attachment of spring coil at the tip of the transducer, which is found to be most convenient to intro- 
duce, to support and to operate the transducer in the heart lumen.

Prior to application to the patients, in vitro and animal experiments were performed to test the possibility and accuracy of this C-scan method and to establish the principle.

On 20 patients with various heart diseases, the probes were used for obtaining information or image of the interatrial septum by this technique without any complication. On 15 patients of them, some information about the septum such as existence, location, size and shape of the atrial septal defect proved by surgery were successfully obtained by either C-scan technique (8 cases) or ECG-synchronized A-scope monitoring ( 7 cases). In some cases, however, the gate setting was difficult in the C-scan.

Monitoring by ECG-synchronized A-scope with the same intravenous probe has been approved rather practical for taking a dynamic three-dimensional information of the septum from various reasons, one of which is that monitoring by the A-scope does not require to set the gate.

The experiences with some difficulty of the G-scan examination have led this study towards improvement of the technique of ultrasonic tomography of the heart by plan-position-indication (PPI) display that is another principle of automatic scanning to produce a three-dimensional image of the heart structure. The PPI display of the heart is described in separate papers.

\section{ACKNOWLEDGEMENT}

The author expresses his sincere gratitude to Professors S. Kimoto and S. Hatano for their guidance, to Associate Professor M. Saigusa, Dr. M. Hori and Professor K. Atsumi for helpful advice, to Drs. M. Tsunemoto, Z. Yamazaki, K. Suma, T. Toyoda, Y. Sakurai, M. Hirose, T. Muroi and Y. Fujimori for their help and to Mr. R. Uchida for his technical help.

\section{REFERENGES}

1. Gordon, D.: Med. Elect. Biol. Engin. 1: 51, 1963.

2. Edler, I. and Gustafson, A.: Acta Med. Scand. 159: 85, 1957.

3. Hertz, C. H.: Med. Elect. Biol. Engin. 2: 39, 1964.

4. Cieszynski, T.: Archiwum Immunologii i Terapii Doswiadczalnej 8: 551, 1960

5. Omoto, R., Atsumi, K., Hori, M., Suma, K., Toyoda, T., Sakurai, Y., Muroi, T., Fujimori, Y., Hasegawa, T., Tsunemoto, M., Sugiura, M., Saigusa, M., Uchiyama, A., Uchida, R., and Nagasaki, K.: Jap. J. Med. Elect. Biol. Engin. 1: 90, 1963.

6. Omoto, R., Atsumi, K., Muroi, T. Hirose, M., Tsunemoto, M., Sugiura, M., Saigusa, M., Uchida, R., and Nagasaki, K.: Jap. Med. Ultrason. 3: 35, 1964.

7. Omoto, R., Tsunemoto, M., Hirose, M., Muroi, T., Hori, M., Saigusa, M., Kimoto, S., and Uchida, R.: Digest of the 6th International Conference on Medical Electronics and Biological Engineering, 296, 1965. 
8. Kimoto, S., Omoto, R., Tsunemoto, M., Muroi, T., Atsumi, K., and Uchida, R.: Ultrasonics, 2: 82, 1964 .

9. Wild, J. J., Crawford, H. D., and Reid, J. M.: Am. Heart J. 54: 903, 1957.

10. Hertz, C. H. and Edler, I.: Acoustica 6: 361, 1956.

11. Oka, S., Tanaka, M., Kosaka, S., Ebina, T., Kikuchi, Y., Uchida, R., and Hagiwara, Y.: Digest of the 6th International Conference on Medical Electronics and Biological Engineering, 294, 1965.

12. Omoto, R.: Ultrasonic tomography of the heart: Ultrasonics 5: 1967 (in press). 